\title{
HENRY CROSS-GROVE, JACOBITE, JOURNALIST AND PRINTER.
}

\begin{abstract}
A 7 HEN Mr. Pickwick made his cele1.3 (2) brated excursion to attend the EatanC. Awill election, he 'took the Norwich 9. 8 coach'; and, apart from this slight 4.2. 6 indication, Dickens did not assist his readers by telling them in what county Eatanswill was supposed to be situated. It, however, seems to be agreed that Sudbury, in Suffolk, was the town described, though I do not think that the originals of the rival editors, Pott of the 'Gazette,' and Slurk of the 'Independent,' have yet been identified. But if Dickens had seen John Chambers's ' General History of Norfolk,' published in 1829, eight years before the 'Pickwick Papers,' he must have gained a hint from it for his account of the squabbles of the rival editors. The following newspaper quotation is in the 'General History.' It is an attack on Henry Cross-Grove (as he wrote his name), the writer and printer of the 'Norwich Gazette,' and was taken from the 'Norwich Courant,' a whig opposition journal which commenced in 1714 ; -
\end{abstract}

Dico Don Quacko offers his services to cure Henrico Cross-Rogo of his wounds, for his just merit, glotiousily 


\section{HENRY CROSS-GROVE, JACOBITE. 207}

managed, and if the intermitting feaver should happen to return, the cortex is ready, alias a whip or rope: and in a few days will be published, 'Memoirs of the Infamous life and Inglorious actions of $\mathrm{Mr}$. Scandal, alias Crossroge, with his flight from Redcross Alley, near Cripplegate, London, very diverting and entertaining, printed on a neat elzevir letter in a pocket volume, by a gentleman lately come from London.

What incident in Cross-Grove's life this referred to is uncertain, nor do the threatened Memoirs ever seem to have been published, but the passage is quite in the style of the amenities exchanged between Pott and Slurk, and the study of a nearly complete file of Cross-Grove's 'Norwich Gazette' has brought the conviction that Dickens must, at some time or other, have seen this Jacobite journal.

Cross-Grove was a man of decided eccentricity in character-one who would at once have captured Dickens's interest.

Apart from this there are two reasons why his biography should be written, the first and not the least important being the fact that of all the early provincial printer-editors he is the only one whose career can be told in detail; and the second being that amongst country editors he alone displayed an interest in contemporary literature. His ambition was to write a magazine. He never quite realised it, but the attempt to do so lifted his paper out of the ordinary ruck.

At the time when Cross-Grove's career commenced, Harley was a Member of Parliament for King's Lynn, and Norfolk was one of the great 
208 HENRY CROSS-GROVE, JACOBITE,

whig counties. Norfolk has a very ancient connexion with the newspaper press. Nathaniel Butter was born near King's Lynn (according to the 'General History'), and so was Dr. William Watts, the Royalist clergyman who translated most of Butter's later 'Corantos' for him. Above all, if we except the Oxford 'Aulicus' and 'Gazette' (afterwards the 'London Gazette'), for which special circumstances accounted, Norwich itself was the first provincial town to possess a newspaper, in the shape of the 'Norwich Post,' commenced in September, 1700, by Francis Burges.' Cross-Grove did not start his 'Gazette' (as it was at first styled) until 1706 , and his paper must have brought him into touch in later years with the famous Dr. Johnson, through the celebrated Edward Cave, who founded the 'Gentleman's Magazine' in 1731. When Cave died in I 754, Dr. Johnson, as his chief contributor, wrote his life. In this the Doctor says that while Cave was 'bound prentice to Mr. Collins,' the deputy alderman and printer in London, 'he was sent without any superintendant, to conduct a printing house at Norwich, and publish a weekly paper. In this he met with some opposition, which pro-

- There are two claimants to an earlier origin. 'Berrow's Worcester Journal' asserts that it commenced in 1690-it may be able to trace its descent from the Jacobite 'Worcester PostMan,' founded in 1709, but it was certainly not founded in 1690 -and the 'Lincoln Rutland and Stamford Mercury' claims to have commenced in 1695 . This latter paper commenced as the 'Stamford Mercury' as late as 1732, and has no connexion even with an earlier 'Stamford Mercury,' commenced also in the eighteenth century. 


\section{JOURNALIST AND PRINTER. 209}

duced a public controversy and procured young Cave the reputation of a writer.'"

It seems probable that the 'Norwich Gazette' was the paper referred to, for Cross-Grove continually advertised Cave's 'Gentleman's Magazine,' and frequently quoted from it. There can be little doubt that Cross-Grove bad much assistance from Cave, and it is not possible to refer the personal attacks in the 'Courant' to Cave. Another great friend of Cross-Grove's was Strype, the ecclesiastical historian, who, by the bye, was a whig, and gave Cross-Grove some good advice. Strype was vicar of Low Leyton, Essex, where Cross-Grove was born, and had baptized him.

Henry Cross-Grove was born on 14th August, 1683 , his father, Patrick, being an Irishman. His mother, Elizabeth, was the daughter of Henry Gutteridge of Leyton, and the widow of John Fellows of London. Patrick Cross-Grove lost his life in the Revolution in $\mathrm{I} 688$, and Mrs. CrossGrove married again three times, her last husband being one Charles Carr, silk-throwster, of Cock Lane, Shoreditch, whom she married on 2 Ist April, I7I 5 .

At first, Cross-Grove entitled his periodical 'Gazette,' simply, and it was merely a piece of paper printed on both sides. Few copies of the earlier numbers exist. Later on it bore the title

'It has been suggested that Cave conducted the 'Norfolk Courant;' I think on no better authority than that the publisher of the 'Courant' was also named Collins. It is not, however, in the least likely that the deputy alderman would have left London to commence business in Norwich. Nor could he have been a Whig. 


\section{HENRY CROSS-GROVE, JACOBITE,}

'The Norwich Gazette,' with, at first, the inside title of the 'Loyal Packet,' ' and later of 'CrossGrove's News.' When Cave started the 'Gentleman's Magazine' the inside title soon became 'Cross-Grove's Magazine.' It was then a goodsized sheet of four pages.

In the year 1715 Strype and Cross-Grove renewed their acquaintance and commenced an interesting correspondence. Cross-Grove advertised Strype's books for him gratuitously, telling him to give his uncle Gutteridge at Leyton the shilling stamp duties, with an injunction to drink his nephew's health with them. Cross-Grove's letters give an amusing account of the petty persecution he endured on account of his Jacobite principles.

On 2nd December, 1714, he wrote to Strype:-

As to what you mention of 'Bp. Whitgift's Life,' I will communicate it to all such as $I$ think likely to subscribe, will be myself a subscriber and do what service I can in it, and will publish your proposals in my newspaper, which spreads all over Norfolk and Suffolk, part of Lincolnshire and Yorkshire. The city of Norwich is at present distracted with party rage-Whig and Tory, High Church and Low Church; or, to give it in our own dialect, Croakers and Tackers make the two contending parties. The Whigs are a strange compound body of false-churchmen, Presbyterians, Independents, Anabaptists, Antinomians and Quakers, each of which have separatists from them, and all conventicles to assemble in. These men think they have got the ascendant and threaten destruction to all who join not with their Republican notions of government, and, as my

'See 'Bibliothece Norfolciensis.' 


\section{JOURNALIST AND PRINTER. 2 II}

business is publick, and my writings as well as principles counter to theirs, I am continually binding over and prosecuting by juries. And thus stand 1 , the Butt of Factious Hate, but Immobile Saxum (l) ${ }^{2}$

This is rather like Pott's declaration to Mr. Pickwick :-

The contest shall be prolonged so long as I have health and strength and that portion of talent with which 1 am gifted. From that contest, sir, although it may unsettle men's minds and excite their feelings and render them incapable for the discharge of the everyday duties of ordinary life; from that contest, sir, I will never shrink till I have set my foot upon the 'Eatanswill Independent.'

\section{Cross-Grove continues :-}

I have sent you my last week's 'Gazette,' together with one 1 printed on 29 th January last [Charles 1 . was beheaded on 3oth January, and Cross-Grove never forgot to celebrate the anniversary by a poem], for which I stood a severe shock from our glorious B. [Bishop Trimnell], and, though I was then censured for writing on that subject, I believe I shall not spare them an inch next time; for I am not yet certain whether 'tis now a real crime to be loyal.

Writing on 21st March, 1714-1 5, Cross-Grove tells Strype of an election not unlike that of Eatanswill :-

The church interest is strangely thrown here, for the Whigs have carried their members, both for city and county; and at the election of the latter they were so outrageously insulting that they drove the Church candidates off the hill with brickbats and stones, and had the

' Copies of these letters are in the Cole MSS., vol. 5853 (Add.). 


\section{I 2 HENRY CROSS-GROVE, JACOBITE,}

impudence to spit in Sir Thomas Hanmer's face, who headed up the clergy to vote for Sir Ralph Hare and Sir Erasmus Earle. We are at present but in odd circumstances here, for we have an artillery company raised lately by commission from my Lord Townshend, who being all of the Oliverian Club, strangely insult and dragoon us, and steal gentlemen's horses who are of a contrary kidney to themselves. They have drawn up a petition to the R. and Council for the silencing my press, and it was, I hear, signed by the Mayor, several justices of the city, the High Sheriff of the County and our good Dean (Humphrey Prideaux) who all swim in the same stream; so that $I$ am in expectation of beeng taken in the custody of a messenger. But I am prepared for the storm and so but little heed it.

Mr. Pickwick's advice to ' shout with the largest crowd ' in an election contest would not have found favour with Cross-Grove, and the consequences of siding with the weaker side in this year well-nigh resulted in the close of his career.

In a letter to Strype, dated 'Trinity Sunday, 171 5,' he writes:-

I cannot sufficiently rejoice to hear that such men are in being as Sir Harry Hickes, who have both honour and courage enough to be loyal, and it will, I presume, not be unpleasant that we have persons here, and in Norfolk too, and many of no mean station and circumstances, who are real Englishmen and can never cease to be so. George's birthday was observed here as much as 1 expected; but on the Restauration day we had the greatest rejoicings that ever were known.

On that anniversary the bells rang from two o'clock on the Sunday morning till two o'clock the next day, and the streets were all strewn with sand and flowers. But, 


\section{JOURNALIST AND PRINTER. 213}

what is more observable, Friday last, being the tenth of June [the Pretender's birthday], the streets in many places were strewn so again, and the bells of the city rang again.

The 'Norwich Gazette' for these years does not, I think, exist, so that the actual words with which Cross-Grove attacked his Whig opponents are not known. But in any case he irritated them to such an extent that a few days later he writes to tell Strype that they had prosecuted him for sedition :-

I have sent you one or two of my Gazettes, as you desired, in which you will find I have twice inserted your advertisement. I have also sent you one or two old ones, which cost me some pounds by way of prosecution for them. I was just taken into custody as I received yours; some villians (sic) having made information that I would head up a body of 80 stout fellows with horns on their heads, on the first of August next, and attack the Whiggish Artillery Company, take their arms from them and down with the Conventicles, and that I did also curse the King. All which I can prove to be false by substantial witnesses. The evidences against me are two pretty fellows; one, a vagabond who has been convicted of felony, and publicly whipped for it; and the other a meer ideot. We are here in an irrepressible heat and Informers swarm everywhere.

Strype, in reply, seems to have remonstrated with him for being indiscreet, for, on $15^{\text {th }}$ August, 17 1 5, Cross-Grove tells him:-

I am an utter enemy to changes and have found, by History and Experience both, that poor England has 


\section{HENRY CROSS-GROVE, JACOBITE,}

never gained by the barter, so far your observation is just. Passive Obedience and Non-Resistance is what I contend for, as a shining doctrine of our church; and happy had it been for Britain if her members had practised as well as preached that doctrine; 'tis the happiness of the subject and the safety of the sovereign; but if ever an Usurper should happen to be crowded into the Throne by men of Latitudinarian principles (which I hope will never happen here) I cannot see indeed then what advantage St. Paul's ai ovoa 'Eovora will be to the Church of England. But, ' ne ultra crepidam.'

The Assizes began here to-day; so that my troubles are but commencing; and I am told within this hour that an indictment for High Treason will be preferred against me; the substance whereof is (as I am told, for a copy is denied me) for endeavouring to raise men against His Majesty and for promoting a rebellion, etc., of all of which I am as perfectly innocent as the child unborn. But 1 have been too forward in expressing my approbation of Monarchy and Episcopacy and in lashing such as I believe their enemies; and, therefore, 'fas nefasve' [they] will rid me out of the world if they can. But 'tis but treading in my father's steps, who lost his life at the fatal (I mean happy) Revolution.

Now as to your business, I have got, Sir, only one subscriber yet, notwithstanding I thrice advertised it in my 'Gazette.' But you will see by the enclosed paper, which is printed here in opposition to mine, perhaps a reason for it. The verses there entitled 'The Tories beat,' \&c. is a Pamphlet of my own, which I wrote and printed upon the Dissolution of the parliament that impeached Dr. Sacheverell and then entitled it a 'Mock Elegy on the Never to be Forgotten Earl of Aminidab's many headed Beast, who vanished "in Fumo" anno 1710.' 'Tis word for word as I then printed it, except in two or three places, where you will easily see they have retorted some names upon me. 


\section{JOURNALIST AND PRINTER. 215}

On 29th August, 1715 , he says:-

I have sent my last 'Gazette,' where you will find I am honourably acquitted.

Cross-Grove published a great deal of very inferior poetry in his paper, besides admitting correspondence on a variety of subjects. He made verses himself and professed an unbounded admiration for Pope, in whose honour he printed a number of elegies, written by himself and his subscribers, and even the full text of the poet's will. Two small volumes of poetry and correspondence, coupled with his own answers, were printed by him in 1708, entitled respectively, 'The Accurate Intelligencer' and 'A pollinaria.'

In his later years he became town councillor for Mancroft Ward; and, perhaps owing to this the following delightful elegy ' on the death of Alderman Churchman' (of the same ward) was the result :-

Descend Calliope, celestial Maid

Assist my labour and my numbers aid

Or rather, $O$ ye Nine, my verse inspire

And grant me all a Poet's sacred fire

Say, what could cause this Rich Display of Woe?

What taught this Breast to heave, these Tears to flow?

Say, is there dead, whose Virtues all men knew

Excell'd by None and Equall'd but by Few.

Whose actions Noble, gen'rous, unconfin'd

Bespoke the inward Candour of his Mind, \&rc.

This might have been written by the young lady who 'did' the poetry in the 'Eatanswill Gazette,' and appeared as a Sultana at Mrs. Leo 


\section{HENRY CROSS-GROVE, JACOBITE,}

Hunter's 'fête champêtre.' But Cross-Grove could write better verse than this, and occasionally even indulged in Latin. He had a great admiration for 'that sweet singer Stephen Duck'-the farm labourer whom the Queen pensioned, somewhat to Pope's disgust. But his love for poetry did not prevent his selling quack medicines. That 'Noble Elixir' of Daffey's was puffed by him in nearly every number of his paper, and the cures reported by him are incredible. Only second to 'Daffey's Elixir' was a 'Sovereign Salve' at 2s. a roll, also sold by him at his printing office. Country printers in those days could not make a living out of printing, and Cross-Grove's solitary important book, a new translation of Josephus, does not seem to have been a success. It has not survived.

He had a way of taking the subscribers to his paper into his confidence about his own affairs which is distinctly funny. On $14^{\text {th }}$ August, 1731 , he tells them :-

I have one piece more of drumstick news (as Ralph. once called it) namely, that as this is the Anniversary of My Own Birthday, in which I enter the 49th year of my Age, I intend to remember all my Honest-hearted Friends and Customers over a Glass of the Best.

The 'glass of the best' was, as we know from his own poems, ' nut brown ale.'

He detested tea, which, he says, was drunk twice a day, at ten in the morning and four in the afternoon, and broke out into Latin verse on the subject - 
Haec medicis dat opes et mercatoribus herba Haec vobis, o vos, gens muliebris Amor Haec eadem dolor est, vestra et quaerimonia sexu Nec tamen e toto parcius una bibit.

Samuel Palmer, of London, the printer of the Grub-Street Journal, and author of the 'General History of Printing,' completed by the literary imposter, 'George Psalmanazar,' was one of CrossGrove's friends. Perhaps Cross-Grove may even have known Palmer's more famous apprentice, Benjamin Franklin. Palmer's death, of course, was greeted with an elegy, and the publication of his history of printing, not only with gratuitous advertisements, but also by a long poem on the ' Noble Art.'

Cross-Grove's first wife died on the 7 th February, 1742 , at the age of sixty, and he told his readers that she was buried at eleven o'clock at night in St. Giles' Church, Norwich. At this time his vaper was accustomed to appear with a rather $\because$. d engraving of the City of Norwich, by way of frontispiece, but a special illustration was devised to celebrate the sad event, and depicted Death, Time, two skeletons, a coffin lid and a shroud, with 'Memento mori' and 'Ah Vita amisa' (sic).

Towards the end of his life Cross-Grove gave great prominence to the quarrels between the Whig and Tory papers in London. 'Fog's Journat' was the successor (appropriately named) of 'Mist's Journal,' two Tory papers for which Defoe wrote. From Cross-Grove, however, John Fog met with much sarcastic comment. Later 


\section{HENRY CROSS-GROVE, JACOBITE,}

on, the more formidable 'Craftsman' appeared (' that vile Republican paper,' Cross-Grove termed it), written by Nicholas Amhurst, with the support of Bolingbroke and Pulteney. When Francklin, the printer of this paper, was prosecuted in 1731 (under Walpole's administration) and afterwards fined $f_{1} 00$ and bound over for seven years, Cross-Grove delightedly recorded the fact; but as a rule he recommended his readers to peruse the 'Occasional Historian' of the Rev. Matthias Earbery, junior, a Norfolk clergyman, rather than the Craftsman's professed newspaper opponent, 'The Hyp-Doctor.' This latter paper was, perhaps, too abusive for him.

On the 25th September, 1731, Cross-Grove told his readers, with much approval, that in the final number of his 'Occasional Historian,' Earbery, mentioning the case of a man who had lost his ears for libelling the consort of Charles I, said that " $\mathrm{Mr}$. Craftsman deserves the same application of Tortures (if torture they must be called) for abusing the Queen Consort of James II,' and added, 'I think his Nose and Ears bear little competition with the Heinousness of his Crime.'

At last, Cross-Grove himself died, and though there was no one left to write his elegy, a welldeserved obituary notice appeared in his 'Norwich Gazette' for 8-1 5 September, 1744 :-

On Wednesday last (November 12 th) departed this life Mr. Henry Cross-Grove, aged 62. Printer of the 'Norwich Gazette and Magazine' upwards of 38 years. He was a man allowed by all Persons of Ingenuity and Learning to be a Man of Learning, Sense and Spirit. 


\section{JOURNALIST AND PRINTER. 219}

And as his paper did always appear with the greatest Spirit, Integrity and Correctness of any paper yet extant, so we design (God willing) to continue it in the same channel, and hope to give the same satisfaction to all our good friends and customers, and return them our grateful thanks for all their goodness to the printer now deceased, and are incouraged to hope their goodness and future favour will be continued to us his widow and son-in-law, Mary Cross-Grove and Rob. Davy.

J. B. Williams. 